\title{
Island Journeys: Fisher Itineraries and National Imaginaries in Colombo
}

\author{
[ACCEPTED VERSION] \\ Alessandra Radicati \\ a.radicati@1se.ac.uk \\ London School of Economics \& Political Science \\ Houghton Street, London WC2A 2AE
}

Article accepted at Contemporary South Asia (14 May 2019)

This paper explores questions of mobility, ethnicity and spatial imaginaries in Sri Lanka through the experiences of fishermen in Mutuwall, a neighbourhood of Colombo. While scholars of Sri Lanka have explored the historically contingent nature of Sri Lanka's island-identity, this paper engages with the contemporary construction of island-ness through ethnographic fieldwork with $21^{\text {st }}$ century residents of the city. Through fishers' accounts of their pre-war itinerant lifestyles and their experiences living in the coastal High Security Zone during the civil conflict, this essay juxtaposes the free movement of fishers before the war with the heavily restricted movement they experienced at the height of the tensions between the Sri Lankan state and the Liberation Tigers of Tamil Eelam. Fisher itineraries can be understood as dovetailing with state imaginaries of island-wide sovereignty even as they challenge it by describing subaltern movement through space. Ultimately, this paper suggests the importance of contemporary modes of "doing" Indian Ocean studies.

Keywords: Sri Lanka, fishermen, Indian Ocean studies, mobility, ethnicity

Is Sri Lanka an island? The common-sense reply to this query would seem to be a resounding “yes," yet recent scholarship has placed Sri Lanka's island geography in question (Jazeel 2009, Spencer 2014, Sivasundaram 2013). In these studies, the country's island identity is not merely an unproblematic geographical fact, but rather a historically contingent and contested way of seeing Sri Lankan space which emerged alongside the European colonial project. ${ }^{1}$ For example, it was not a foregone conclusion at the start of British colonial rule that Sri Lanka should necessarily be administered separately from British territories in India (Spencer

\footnotetext{
${ }^{1}$ While colonial rule was a highly important source in the production of Sri Lanka's island identity, Tariq Jazeel's (2009) incisive analysis reminds us that the consolidation of British rule in 1815 was not the sole source of these geographical imaginaries; Jazeel demonstrates through analysis of multiple historical sources that the notion of a unified Sri Lankan island space in fact pre-dates British colonialism.
} 
2014, 2). Equally, the process of consolidating colonial rule over the entire island was not frictionless; it eluded all colonial powers until the British conquest of the Kingdom of Kandy in 1815; up until this point, "Sri Lanka" was not a single space dominated by one kingdom or ruler, but rather a cluster of different societies (Jazeel 2009, Wickremasinghe 2006).

As Sujit Sivasundaram shows in his monograph Islanded: Britain, Sri Lanka, and the Bounds of an Indian Ocean Colony, "islanding" was an active process - this included actual material efforts to separate the two landmasses by dredging the channel between Sri Lanka and India (Sivasundaram 2013, 14). As Sivasundaram puts it: “To understand 'islanding' it is important not to take the physical geography of islands at face value, or to assume that the localness and boundedness of the island is natural" $(2013,25)$. Alongside such efforts to physically separate Sri Lanka, however, recent historical studies of Sri Lanka have also pointed to the numerous linkages - religious, economic and intellectual - between the island and its neighbors, both before and during British colonial rule (Blackburn 2010, Wenzlheumer 2007, Roberts 1980, Frost 2002, Biedermann and Strathern 2017). ${ }^{2}$ Sri Lanka's island-ness thus exists in contrapuntal relationship to its long history, dating to precolonial times, of interconnection and cosmopolitanism across Indian Ocean and Asian worlds.

These critical readings of Sri Lanka's island-ness coincide with a broader trend in contemporary studies of South Asia which shifts focus from the subcontinent outwards to the broader Indian Ocean world (e.g., Ho 2006, Green 2011, Amrith 2013). Increasingly a recognized scholarly field in its own right, Indian Ocean studies has established new terrains of inquiry, dramatically changing how scholars of South Asia comprehend the arrivals, departures

\footnotetext{
${ }^{2}$ Many of these connections involve labor movement between India and Sri Lanka during the colonial period as a result of British policies - these are explored in detail in Wenzlheumer (2007). However, as shown in work by Anne Blackburn (2010) and Biedermann and Strathern's (2016) recent volume, as well as in Roberts (1982), pre-British colonial connections have been significant as well.
} 
and circulations which have inflected the region's economic, political and religious life for centuries. Through the lens of Indian Ocean studies, migration, mobility and transnational connection are key themes which allow scholars to challenge, among other things, ethnonationalist myths of purity and stable, unchanging identities. Given the violent legacy such myths have wrought in the South Asian region (as elsewhere), Indian Ocean studies are a welcome corrective to overly sedentarist, isolationist and parochial modes of doing history. But the importance of questioning Sri Lanka's island-ness is not merely a historical exercise. As Tariq Jazeel explains, "Sri Lanka's bloody civil war was fundamentally about territory. Specifically, it was about contested claims over the island geography of the Sri Lankan nation-state" (Jazeel 2009, 399). The conclusion of the Sri Lankan civil war, less than ten years ago in May 2009, suggests that the process of working out these questions of territoriality and spatiality are not relegated to a distant historical past. In this article, I consider the production of Sri Lanka's island-ness through the $20^{\text {th }}$ and $21^{\text {st }}$ century experiences of the fishing community at Mutuwall, northern Colombo. I suggest that rather than see "islanding" as a process begun and completed within a discrete historical timeframe, we might view Sri Lanka's island-ness as a reality that is being continually produced and reproduced. How can we consider the making of Sri Lanka's island-ness not only historically - through reliance on the archive - but ethnographically, through the lives of contemporary residents of its largest city?

The discussion presented here stems from several months of ethnographic fieldwork carried out in Mutuwall as part of my broader research agenda focused on urban development and imaginaries in post-conflict Colombo. The fishing community at Mutuwall is made up of about 200 low-income families, many of whom migrated to the area from Negombo and other parts of the Western Province in the late 1960s and early 1970s. From its original role as an 
outpost to dock boats and take advantage of favorable tidal patterns, Mutuwall has grown into a stable community of low-income urban residents who live there full-time, send their children to local schools and practice fishing as well as other forms of labor ("land jobs") primarily associated with the nearby bustling Port of Colombo. Fishers are socially marginalized and economically precarious, often navigating multiple different threats to their livelihood and land tenure and negotiating a relationship to the Sri Lankan state that is by turns neglectful, violent and repressive.

Mutuwall, I found, offered many important counterpoints to the linear narratives of economic development which dictated the dramatic transformations of urban space. While the Sri Lankan state celebrated Colombo's potential as a future "hub city" in Asia, akin to Singapore or Dubai, urban poor communities living on valuable coastal land not far from the heart of the city's financial and tourist infrastructure had no obvious place in the representation of the Sri Lankan capital as a wealthy, modern metropolis. In this context, fishers and other members of the urban poor feature as living anachronisms - inconvenient reminders that "backwards" or "traditional" (to use the adjectives employed by my middle class friends and informants) ways of life persisted despite rapid urban development. But Colombo's divera aiya (fisher people) provided many contradictions to traditional nationalist narratives of ethnic purity as well: Mutuwall fishermen and their families occupy a precarious position at the material and symbolic edge of the Sri Lankan nation-state. As religious minorities and people of mixed ethnic background in a Sinhala-Buddhist nationalist context, fishers were distinct from inland peasants and rice farmers who are equally "traditional" but who serve as deeply sympathetic figures in the nationalist imaginary. Inhabiting a stretch of coastline threatened by erosion and under constant threat of displacement and relocation (AUTHOR, under review), Mutuwall residents experience 
a litany of challenges and concerns common to the urban poor in Colombo, and across the Global South more broadly. Mutuwall's spatial location - within view of Colombo's downtown financial district and only a brief journey from the Port, the heart of the Sri Lankan economy belies its social location as a space largely overlooked, or even actively avoided, by Sri Lankan state agencies and the Colombo middle class.

In what follows, I present fishermen's accounts of their pre-war itineraries around and through Sri Lanka's island space. I consider these itineraries as a more recent form of production of Sri Lankan island-ness. I also engage fishers' descriptions of life on the coastline during the time of the High Security Zone (HSZ) established as a measure to safeguard against attacks by the Liberation Tigers of Tamil Eelam (LTTE). Ultimately, I use this ethnographic material to advocate for more attention to the complexities of Sri Lanka's islanded-ness, both internally through a closer look at life within Colombo - and externally, as a means of engaging with Indian Ocean studies in a contemporary register.

\section{Fisher Itineraries}

In June 2015, I was conducting fieldwork in Colombo when Father Thomas and Sister Jane ${ }^{3}$ Roman Catholic clergy-members and social activists whom I had known for some time, invited me to accompany them on a trip to a northern neighborhood of the city, located just north of the Port of Colombo. Upon arrival, we took a winding path down from the main road to a small fishing enclave known as Mutuwall. As we toured the narrow streets of the fishing enclave, people emerged from their houses to greet us. Shrines depicting the Virgin Mary and Baby Jesus, wooden crosses affixed to doors and walls and murmurs of "God Bless you"

\footnotetext{
${ }^{3}$ All of my informants have been given pseudonyms and in some cases specific identifying information has been altered in order to protect their anonymity.
} 
directed at Father and Sister indicated that the area was heavily populated by Roman Catholics. Joining us was Anushka, a representative from a fisherman's union in the city of Negombo, located a short distance north along the coast. Anushka, Father and Sister had come to Mutuwall because together they formed part of a coalition of activists united against a waterfront development project known as the Colombo Port City, which posed a threat to fisher communities because of its potential to disturb marine life breeding grounds, and contribute to coastal erosion. Turning to Anushka, Father asked - barely audible, and in English: "are these people Sinhalese, or Sinhalese-speaking Tamils?"

Father's question pointed to the subtleties and ambiguities of defining ethnicity in Sri Lanka. It drew a subtle distinction between language and ethnicity, revealing through its phrasing one of the nuances of the Sri Lanka's long-running civil conflict, which had ended a few years before: while language came to be one of the most prominent sites of contention between Sri Lanka's different ethnic and religious communities, language or linguistic ability alone do not determine ethnic belonging. Anushka replied without hesitation "these are Sinhalese," and, seeming satisfied with the answer, Father moved on, with me and Sister trailing the two men through the winding walkways of Mutuwall. The question did not come up again that day, and though I jotted it down in my field notes, I did not give it much thought either. It was not until several months later, when I returned to Mutuwall on my own, that its significance was made clear to me.

A few months after my initial visit to Mutuwall, I was sitting in one of the small, low houses in the enclave nestled close to neighboring dwellings, its door open to the main thoroughfare cutting through to the nearby Port of Colombo. Accompanied by my research assistant, Ashan, and a young woman from Mutuwall whom I had befriended, Rebecca, we had 
come to speak with Darius, one of the more senior fishers in the area, who welcomed us eagerly into his home. Shirtless, wearing a plaid sarong, and pulling up plastic chairs for us to sit on, Darius was friendly and spoke in a booming voice as his young daughter, in pigtails and bright pink shorts, danced excitedly around us, clamoring for attention. Rebecca introduced us and left, heading off to do some errands. Ashan and I sat in the plastic chairs, accepting glass bottles of fluorescent Necto soda, brought from the local kade (shop).

I was interested in speaking to Darius about some rumors I had heard from others in Mutuwall, about the possibility of the community being relocated from this highly valuable coastal land into high rise apartment buildings, a fate that was befalling many urban poor communities across the city of Colombo (see CPA 2014 for greater details). Specifically, I wanted permission to examine Darius' wooden front door; I had heard that the relocation plans had involved marking residents' houses with a sticker indicating who would be asked to leave and move into the high rises. With a broad, magnanimous sweep of his hand, Darius motioned for me to go have a look. "Look, you can see it right there," he told me, drawing my attention to a ragged letter "P" peeling and stuck to the door surface. I stared at it for awhile, taking in the sticker which might spell eviction nestled alongside images of Jesus Christ and Pope Francis. Some stickers in Tamil caught my eye. "Do you know Tamil as well?” I asked with surprise, gesturing at them. "Oh yes,” Darius said breezily. "I went to school in Vakarai, so I had to learn it." He smiled at my look of surprise and gestured at his wife, saying her father was Tamil, "and so she is half." She smiled and added "like Rebecca's father," and nodded in the direction of my friend's house. Rebecca had never mentioned any Tamil parentage, but when I asked her about it later, she confirmed what Darius had told me, and added that her husband too had Tamil family members. Her young son was learning the language too, and though she described herself as "not 
very good" at Tamil, she said she was able to understand and watch Tamil films from India.

Over the course of my fieldwork, more and more of these family histories came to the fore: it was exceedingly common for residents of Mutuwall, particularly the fishermen, to have Tamil ancestry. $^{4}$

I highlight these accounts of mixed kinship and intermarriage not as a kind of ethnographic novelty - as my ethnography reveals, this was hardly novel to anyone in the community but me but rather to emphasize the flexibility of ethnic categories in this context. In other words, Anushka's confident answer to Father that the people of Mutuwall were Sinhalese - a comment he made without hesitation, and which was likewise accepted without hesitation - does not necessarily contradict the story of Darius, his wife and others in the area. Rather, it is more productive to consider the ways in which the category of "Sinhalese" is stretched by its inclusion of people with a Tamil parent or grandparent. Through the multi-ethnic heritage of Mutuwall's fishing families, it becomes possible to consider alternative ways of being, identifying as and feeling Sinhalese in Sri Lanka.

Born in the early 1970s, Darius grew up in a fishing family, his father and grandfather both lifelong fishers, originally from Negombo. They used to travel around the country. As Darius explained:

There were hardly any fishermen back in those days, so when we arrived in different places, there was no conflict, no competition. Nowadays, anyone with a boat can call themselves a fisherman. Back then, whole families were traditional fishermen.

\footnotetext{
${ }^{4}$ These discussions of language and kinship echo the findings of Steven Bonta on what he calls "Negombo Fishermen's Tamil," or "NFT." According to Bonta, NFT is a particular form of Tamil, distinct from formal or "standard" Tamil spoken in other parts of the island; specifically, NFT's grammar has evolved over time in ways that make it more similar to Sinhalese grammar. As Bonta notes, "in the zone from Negombo to Chilaw, the Catholic fishermen, unlike most of Sri Lanka's other Tamil-speaking communities, are bilingual in Tamil and Sinhala and, in general, identify themselves as Sinhalese, not Tamil" (2010, 310). While the ethnography presented in this paper takes place in Colombo, which is south of the zone Bonta describes, most of the fishermen I interviewed told me they or their parents had originally come from Negombo.
} 
Author: Where would you go?

Darius: Everywhere, we would go to every village [all parts of the island] by sea. Those days were not like today, fishermen traveled everywhere, all around the country. We would build a small village and then travel again. We made our houses out of palm leaves...The Feast of Saint Sebastian [the feast of their home Church in Negombo] is once a year on January $25^{\text {th }}$ so we would come back for that. Otherwise that is the only time we would return.

Author: what path would you take, where did you start and where did you go from there?

D: We would start out from Negombo, then...where was it? Then Mannar, then Jaffna...sometimes to make it back on time for the feast, we would have to leave the boats wherever they were, and come back over land to Negombo.

Author: So what happened then? How long did this continue?

D: After LTTE problems came [this lifestyle] stopped. There were no problems with government or bureaucrats before the war. You could go around alone. Now people from Negombo stay in Negombo.

Author: Were there ever any tensions or problems with Tamil people at the time, when you would go to the Tamil villages on your travels? Weren't they there too, fishing?

D: [laughing] Oh! That's a story! [We are briefly interrupted by Darius' father speaking to us] The Tamils were afraid of the Sinhala fishermen when they saw us, people would shout abuse and discrimination, but then would keep quiet and say nothing. When they saw us sell to the mudalali [local merchant], they realized then they were not allowed to hound us.

Darius continued:

Those days there was not much navy or army presence. But one day we were out at sea and saw [the Sri Lankan] Airforce bombing the LTTE as they were in the sea as well, in the same water [as us]. The LTTE brought their boats to shore and took off running. This was a shock, [it was] the first time we had ever seen anything like that.

In Darius' account, the beginning of the ethnic tensions between Tamils and Sinhalese spelled the end of this itinerant lifestyle: "I was eight or nine when we came back to this area at the end of the 1970s. There were lots of prawns in Vakarai over in the east," he concluded wistfully. I asked whether he and his family, or others, had ever considered that they might keep traveling after the ethnic tensions began, but simply stay in the southern part of the island. Darius said this 
was not an option: "there are more fish in the north than in the south," so it would not have made sense. "We lost a lot of income after we stopped going," he said with finality.

Later, I had the chance to speak with Darius' father, Daniel, who reiterated much of the information his son had given us regarding the itinerant fishing lifestyle. Fishermen, Daniel explained, needed to move around to take advantage of more favorable tidal patterns in different parts of the island:

Fishing was more than enough, there were fish about six months of the year, the other six months the sea is rough. So we would go to the lagoon area to fish. When the seas got rough that's when we started to go to other areas, when seas are rough on this side, in the east [of Sri Lanka] the seas are OK.

He continued, describing the East as a distinct location,

Those days those areas [on the the east coast] were not developed. They were living like veddas (ara paette minissu vedda vage), the women were topless or barechested, only after about 4-5 years they started dressing properly, with saris and blouses.

Author: how did you move around? How did you get from one place to another?

Daniel: we used sailing boats, no maps. We would stay close to the land to help navigate. We'd go in search of places, if it was good we'd would stay there, if not we'd go to another place. [Starting about] 10-11 years later, we would take small boats and come inland by train to meet other fishermen. Then lorries would come and we'd pack into them, and go on to the next place. Slowly, gradually, the country developed. On the east side, there were lots of prawns (isso vaedi) you could catch 1,500lbs of prawns in one day...

Author: What about the Tamil people already living there? Was there any trouble?

D: There was no ethnic cleansing, but people would be afraid and just run when they saw us coming.

As the ethnographic vignettes at the start of this section reveal, Mutuwall fishers, including

Darius and Daniel, had complex ethnic identities forged through intermarriage and the widespread of use of Tamil in home and school environments. As Daniel said to me, "it's normal for people from Negombo to speak Tamil.” And yet, importantly, in Darius and Daniel's 
accounts of itinerant fishing, fishers from the western province did not identify themselves as being Tamil, and always spoke of Tamils they encountered in the North as a distinct community, other and separate from themselves. Tamil language ability and kinship ties did not alter the fishers' views of themselves as Sinhalese. These ethnic and linguistic ambiguities stretched the category of "Sinhalese" rather than disavowing it. In the next section, I consider the broader spatial implications of these journeys.

\section{(Re)producing Sri Lankan State Space}

Colombo fishermen's circumnavigation of Sri Lankan island space and the imaginaries of Sinhalese-ness, Tamil-ness and nation-state that these journeys evoke suggest that far from being relegated to colonial or pre-colonial times, Sri Lanka's island-ness is in fact constantly produced and reproduced. "Indian Ocean studies" as a response to "South Asia studies" has been critiqued for being excessively focused on elites; scholarly interest in port cities lends itself very well to understandings of trade and commerce, but not necessarily to the lived realities of those who live on coastlines but do not form part of a mercantile upper class (Subramanian 2009). Similarly, Indian Ocean studies' strong historical focus may obscure the contemporary modes of politics, life and sociality that continue to shape coastal areas. This paper is an attempt to rectify these imbalances.

Fishers' journeys simultaneously replicate the Sri Lankan state's own view of all-island sovereignty, while also complicating received narratives about state-ness, mobility and space. In one sense, the accounts of men like Darius and Daniel mirror the way that many Sri Lankans from Colombo and the Southern and Western Provinces think about the conflict: the civil war was a time when what was once "whole" and unified was torn apart by ethnic tensions. Free 
movement - meaning the ability to move around the island unimpeded - was gradually curtailed. This narrative reinforces the Sri Lankan government's own projection of Sri Lankan statehood as naturally extending across the entire island, with Tamil separatism figuring as a violent, unnatural disruption. Such a way of imagining space erases the violent interferences into daily life of the Sri Lankan state itself, especially with regards to the way that mobility and free movement of Tamil citizens was hugely impacted during wartime.

Several important themes emerge in Darius and Daniel's accounts - themes which were also present in my shorter discussions and interviews with other fishers in the Mutuwall area. The first is the "otherness" of Tamils that they encountered on their journeys to the north and eastern coasts of Sri Lanka - as observed in the last section, this was despite fishers' own mixed Tamil-Sinhalese heritage and Tamil language abilities. Ultimately, these constructions of otherness of Tamils only served to stretch and expand the category of "Sinhalese,"; in other words, partial Tamil descent did not trouble the fundamental identification of many fishers' with Sinhalese-ness. As evidenced throughout their narratives, the other parts of the island were seen as "less developed" in contrast with the more developed and modern western province. In both Darius and Daniels' accounts - and for other fishers as well - the timeline of starting and stopping mobility was associated with the onset of the ethnic conflict.

These stories and accounts of free movement stopped by war echo observations made by Sharika Thiranagama (2012) in her study of the Northern Railway Line which connected Jaffna and Colombo until 1990, when the civil conflict escalated to such a degree that its continued usage was impossible. According to Thiranagama, the railway was both a "physical and symbolic representation of stateness" as well as well as a technology of "mundane everyday life" (2012, 223). Like the fishermen's stories, passengers' experience of traveling the Northern 
Railway Line point to the spatial politics of an island divided by civil conflict: what is fluid or open becomes closed, connections severed. People gradually come to stay in place, where once they had moved around. As Thiranagama argues, "in the aftermath of its closure, the railway has come to symbolize the quest for the desired normalcy of the past," (Thiranagama 2012, 223). Similar yearnings for a pre-war past are evident in my discussions with Darius and Daniel.

However, fishers' narratives echo but also complicate state visions of development and nationhood. There are subtle but important ways in which the accounts of Daniel and Darius function as subaltern critiques of the Sri Lankan state discourse. The non-elite character of their livelihood and movement provides a crucial difference between their way of life and the aspirational middle-class focus of contemporary development rhetoric in Sri Lanka. Where railway journeys signify the possibility of state-sponsored, "respectable" movement through Sri Lankan space in a mode intelligible to the imperatives of development and modernity, fishers' journeys point instead to the mobility of people who eschew these infrastructures, and whose reason for movement is tied to subsistence livelihood.

Fishers' accounts thus push us to think through the temporalities of war, conflict and “islanding" in new ways. Though Daniel and Darius' descriptions of their itinerant lifestyles were often related with a wistful, elegiac tone, it is worth keeping in mind that they were talking about memories from the 1950s through to the late 1970s - hardly a forgotten, long-lost era. The inclusion of technologies such as trucks and fishing boat engines in their accounts acts as a reminder of the distinctly $20^{\text {th }}$ century nature of their travels. As mainstream development rhetoric in Sri Lanka optimistically proclaims that the end of the civil war has been a catalyst for modernization and change, it can be jarring to recall just how recently - perhaps hauntingly so - 
the war actually took place. Less than a decade after the end of the civil conflict, memories of violence and repression still linger on the Colombo coastline.

\section{Life in a High Security Zone}

"We follow the fish, the fish don't come to us"

- Mutuwall fisherman, 2015

Because of its proximity to the Port of Colombo, Mutuwall was located in the midst of a High Security Zone (HSZ) for part of the conflict. The Sri Lankan government feared that LTTE attacks on the Colombo port would have disastrous consequences for shipping and commerce, and as such large stretches of the Colombo coastline were controlled by the Sri Lankan Navy. One day, my friend Rebecca took me and my research assistant, Ashan, on a walk around Mutuwall - we went past the last of the houses and walked for a few minutes onto a rocky outcropping which led to a decrepit old building the fishermen referred to as "the lighthouse." As we walked, Rebecca gestured back towards Mutuwall, the houses arranged in a crescent shape around the stretch of beach. She spoke of the marine life in the area, and described the yearly blessings bestowed by a local priest on the fishing boats. When we came back to Mutuwall proper, she mentioned off-handedly that the very area where we had just been walking had once been part of the HSZ: the casual stroll we had just taken would have been illegal before 2009 .

The HSZ had disastrous consequences for fishermen and their livelihoods. Restrictions on their free movement meant that fishers could be punished if they were caught out at sea in their boats; many were terrified of being mistaken for LTTE operatives and killed on sight. However, the alternatives to fishing were slim. Without much training in other forms of work, many fishermen in Mutuwall spoke of the HSZ years as a time when "the fishermen did not eat," 
a reference to the severe conditions they faced as they sought to make do through a combination of secret fishing, "land jobs" and occasional illicit activity.

Through Rebecca, I met Joseph, a fishermen in the area whose family had been among the original residents of Mutuwall, having settled in the area in the 1960s. Joseph recalled the fear brought on by the 2004 Indian Ocean Boxing Day tsunami, but explained that unlike some families who chose to leave Mutuwall and accept being resettled by the government elsewhere, he - like others - had chosen to stay in order to be near the sea. After chatting for awhile, we turned to the subject of the High Security Zone:

For three years we barely had anything to eat, we couldn't go fishing. ... we didn't want to riot or cause trouble, the country's security was more important [than fishing]. Day and night the area was guarded. Because of the country, we kept calm. I got a navy pass, so I went to fish in Handela for a bit. You couldn't even walk on the rocks without a pass. [Here, he gestured in the direction of the lighthouse.]

Joseph described the different jobs he and others in Mutuwall took on to make it through:

During this time, there were different survival strategies. People worked in packing jobs, labor jobs, they worked in fish markets selling fish, some joined Abans [the cleaning service]. My sister's son, my nephew, he has an animal farm, a pig farm, and so I would sometimes go sell pork with him.

The Sri Lankan Navy could be brutal with any fishermen caught out at sea without a permit. Permits might allow a fisherman to go elsewhere on the coast, but all the Mutuwall fishers explained that the waters around Colombo, particularly the Galle Face Green, were where the best fish, lobsters and crab could be caught. This was the heart of the HSZ, and fishers made their ways here at great risk.

Joseph himself had had some bad run-ins with the Navy, He had been beaten many times. He described one incident: he had gone out fishing with some younger male relatives - his nephew and his niece's husband. But he had been ill, and while at sea was struck with a high 
fever. The other men tried to get the boat back to shore quickly to get Joseph home, but the Navy caught them in the HSZ. When they explained the situation to the naval officers, they weren't arrested or beaten but the officers seized the boat for 24 hours. "You can't blame the navy, they are doing their job" he mused. "But the fishermen have to take care of their families. We'll starve otherwise."

William, another fisherman in the area, was significantly younger than Darius, Daniel or Joseph, but he too recounted harrowing experiences at sea. Though he was not old enough to remember the times before the war, William was a teenager when the HSZ was put in place in the early 2000s. One day, when he was out with some other fishermen, their boat's engine broke and they were left bobbing in the waves. A Sri Lankan Navy vessel approached William and his companions and - realizing that they could easily be mistaken for LTTE operatives - he and his friends began shouting Sinhala. Luckily, the navy did not fire on them but arrested and detained them instead.

"We have to do whatever we can to help our families," William says. He described the Sri Lankan Navy as "taking out" their aggression towards losses to the LTTE on fishers down in Mutuwall. Whenever the Navy boats would be bombed up in Jaffna, he claims, naval officers here in Colombo would throw the fishers' catch back into the sea. Rebecca concurred, telling a story of her husband's uncle, whose boat was split in two by the Navy officers for no reason. "A lot of injustice happened to the fishermen," William observed. Nonetheless, fishers expressed the same fear of the LTTE as much of the rest of the Colombo population. And though the fear they expressed was usually described as being caused by LTTE attacks, most of the violence visited upon fishers came from the Sri Lankan security forces. Despite this, fishers frequently punctuated accounts of injustice at the hands of the security forces with praise for those same 
security forces. Being Sinhalese - that is, qualifying as "Sinhalese" in a snap assessment of ethnicity - had its benefits, no matter what other hardships fishers experienced. Another time, William was caught in the HSZ waters with a group of other men, and, he said the Sri Lankan naval officers told them, "we're letting you go because you're all Sinhalese. Otherwise, we would kill you here." These words recall the equally quick and easy assurance of Anushka to Father Thomas, in a previous section, that Mutuwall fishers were categorically "Sinhalese."

Fishermen's accounts of the HSZ years reveal the material hardships caused by the civil conflict, even for a population living within the heart of metropolitan Colombo. In fact, the fishers' proximity to the Colombo Port - perhaps one of the most enduring symbols of Sri Lanka's global connections and cosmopolitanism - was the very thing that caused so much tension between them and the security forces. Official documents and rhetoric about Colombo's development usually overlook the presence of the fishers in this part of the city, painting a picture of the Colombo Port and its environs as existing only to service the needs of capital (Nagaraj 2016), not as a home to urban fishermen. Central but peripheral at the same time, the fishermen at Mutuwall escape notice. And yet they needed to eke out an existence in the very water that was subject to the military logic of security during a time of armed conflict: hostile waters indeed.

The narratives of William and Joseph highlight the slow closing down of avenues of marine circulation. The use of the Sri Lankan Navy pass to allow fishers only into particular areas suggests a stark contrast with the free movement described by Daniel and Darius from the years before the war. Fishers' accounts trace a history of a few decades, in which the thread of the story resembles a tightening noose around fishermen's necks. Free movement, as seen here, is not a luxury but a matter of survival. These stories also foreground the fraught nature of 
"islanding" as a process; as the Sri Lankan state waged war with the LTTE to maintain control over the entire island territory, this necessitated a change in the way that highly mobile populations, such as the Mutuwall fishers, were treated. Islanding, then, comprises both free movement and restriction.

\section{Island Imaginaries}

How do stories of remembered mobility and past journeys relate to the process of "islanding"? What do Mutuwall fishers' experiences of living in and coping with the HSZ tell us about the Sri Lankan state's territorial claims? And how do ethnicity and territory work together to produce imaginaries of a unified Sri Lankan state space? Bart Klem's work on territorialization and circulation offers a useful entry-point for addressing these questions. For Klem, territorialization and circulation are not opposites but, rather, a mutually constitutive "conceptual pair" $(2014,35)$. "Territorialization," he reminds us, "is about regulating and influencing flows, rather than mitigating them altogether" $(2014,35)$. Building on this, I contend that the histories of relatively free movement narrated by the fishermen, followed by the period of harsh restriction and confinement experienced during the HSZ can indeed be understood together as part of a larger pattern of the territorialization of the state in postcolonial Sri Lanka. Rather than presenting these two time periods - pre-war and war - as sharply distinct, I suggest that the ethnographic material offered here trains our gaze instead to the complex ways that Sri Lankan island space has been imagined and produced both through ideals of "pure" ethnic origin mapped onto territorial belonging, as well as through actual patterns of movement - including the interruption of such movement. 
Mobility and ethnicity are linked. Sri Lanka's multi-ethnic, multi-religious makeup and its long-running conflict appear particularly complex precisely because people move around. Despite the fact that both Sinhala-Buddhist and Tamil nationalisms depict different ethnoreligious groups as "belonging" to specific spatial locations, much of the complexity of Sri Lankan politics stems precisely from the fact that ethnic groups do not neatly conform to the maps and territorial imaginings assigned to them by these nationalist visions (see Venugopal 2018 for further discussion of this). As Jonathan Spencer explains:

Within the island there is a great deal of movement, much of it officially sponsored and intended to 'protect' or 'preserve' the indigenous peasantry, the 'sons of the soil', whose natural virtues are the other side of the coin of purification. Policy is oriented to a world of clear boundaries and exemplary essences. But all the while the impurities linger and multiply. (Spencer 2003, 12)

Spencer's observation reminds us of the link between "peasantry" and "purity" in Sri Lankan politics, even as the former is often a product of government schemes to strategically relocate and move people in order to shore up agrarian communities who can then be read as part of "the indigenous peasantry." In different contexts, however, movement is instead noted with suspicion and hostility. Cynthia Caron observes in reference to Kalpitiya, in the western province, that in the context of resistance to a major development project, ${ }^{5}$ residents' "mobility and lack of legal property rights signaled a lack of autochthonous ties, which [were then] constructed as dispensible and shallow ties to the place" $(2007,426)$. Additionally, coastal residents in Kalpitiya were often portrayed as threatening to the Sinhala-Buddhist nation precisely because the coastline was highly securitized and associated with the dangers of both terrorism and

\footnotetext{
${ }^{5}$ Caron's study (2007) examines the "social drama" surrounding the construction of the Norochcholai power plant on the western coast of Sri Lanka in the 1990s. Many of the ethnographic details in Caron's analysis offer interesting points of comparison with the similar, but distinct, fishing community of Mutuwall presented in this article.
} 
smuggling $(2007,426)$. As these accounts suggest, notions of purity and indigeneity as well as what constitutes "acceptable" or "proper" forms of movement differ considerably depending on whether the subjects in question are coastal or inland.

The Sri Lankan state is simultaneously absent from and violently present in Mutuwall fishers' stories. Though the freedom of movement the fishers described in the pre-war years often illuminated a degree of freedom from the state,${ }^{6}$ fishers nonetheless identified strongly as Sinhalese Sri Lankan subjects. This is significant because in Sri Lankan terms, such ethnic identification is never incidental but rather a loaded political claim; as discussed above, fishers' identification as Sinhalese is important because it does not stem from uncomplicated ethnic lineage; to the contrary, it suggests a rather expansive notion of "Sinhalese-ness" which incorporates subjects who are religious minorities (Catholics) and have significant Tamil ancestry. Even when fishers experienced repression and brutality at the hands of security forces, they continued to express allegiance to the Sri Lankan state, and solidarity with the broader aim of defeating the LTTE insurgency. Though "subaltern" in many ways, fishers nonetheless express allegiance to and benefit from Sinhalese supremacy (as in William's story of his encounter with the Sri Lankan Navy). Fishers' trajectories - as Sinhalese citizens - around the entirety of the island of Sri Lanka mirror the state's own ethnicized vision of the island as a unified space, even as their non-Buddhist and non-elite identities speak to their own exclusion from middle-class Sinhala-Buddhist visions of modernity and development.

\footnotetext{
${ }^{6}$ In material terms, many fishers explained that their lifestyles at this time were also made possible by heavy state subsidies on items like petrol (to fuel boats), rice and other essentials. In this sense, the Sri Lankan state's preliberalization policies and the existence of a broad set of social programs may have made the state more "present" though in different ways - than fully absent.
} 
The coastline in Sri Lanka is a highly specific kind of territory, and one aim of this paper has been to consider coastal space in new ways as it is produced by the island's subaltern subjects. While Sivasundaram argues that coastal lifestyles and subjects have been privileged in studies of Indian Ocean history, leading him to direct attention to the importance of Sri Lanka's interior (2013), Ajantha Subramanian asserts that the actually-existing livelihoods and politics of contemporary coastal dwellers in South Asia have been largely ignored, often with the problematic assumption that fishers are simply relics of the past or "quintessential locals mired in static time and space," (2009:5). This ethnography works to address this tension between Indian Ocean studies in its historical and contemporary registers by considering the recent histories and politics of Mutuwall fishers. While the combination of the 2004 Boxing Day tsunami and high levels of violence in the Eastern Province has led to many studies of this portion of the island's coastline (eg. Choi 2015, Hyndman 2007, Lehman 2013, Walker 2010), the coast within Colombo itself has largely been ignored, as has people's movement beyond their own coastal communities of origin. This paper examines a more expansive notion of the Sri Lankan coastline by "zooming out" and looking at how fisher itineraries describe a spatial imaginary beyond the confines of Mutuwall, helping to inscribe an island-wide vision of the boundaries of the Sri Lankan nation-state.

\section{Conclusion}

This paper has used ethnographic research to make a contemporary contribution to both Indian Ocean and Sri Lankan studies. Through the stories and memories of fishermen in Mutuwall, Colombo, I have shown that curtailment of mobility has been central to the experiences of war and civil conflict. This ethnographic data pushes us to consider Sri Lanka's 
"island-ness" as continuously produced and reproduced by contemporary Sri Lankans, rather than viewing it as a distant and already-completed process. Building on the idea that territorialization is not about stopping but rather about controlling or directing flows (Klem 2014), I have considered the way that fishers' narratives fit into the broader agenda of consolidating the Sri Lankan state's power. The type of "islanding" described in this article is distinct from the islanding processes described by Sivasundaram (2013). Rather than setting out to understand how historically Sri Lanka came to be bounded and separate from India and the rest of South Asia, the investigation presented in this paper builds on Jazeel's (2009) points about the territoriality of the Sri Lankan state and the way that imaginations of island space have shifted over time to privilege the notion of a unified, singular entity with power over the entire land mass of Sri Lanka.

Building on Jazeel's (2009) assertion that the Sri Lankan conflict was "fundamentally about territory," I highlight a very specific type of territory - the island's coastlines. As the fishers' accounts detail the dramatic shift from free circumnavigation of the island to the hardships of life in the HSZ, it is clear that the Sri Lankan coastline has been transformed by the logics of security and war. This points to extremely recent modes of constructing Sri Lanka's island space which suggest the ongoing, contemporary relevance of "islanding." It further suggests the importance of understanding Sri Lankan coastal residents' patterns of movement and circulation, themes which have been alluded to in studies by Klem (2014) and Caron (2007) but which are further elucidated here.

Fishers' mixed ethnic backgrounds and histories of intermarriage, travel and exchange with Tamil parts of the island may defy neat nationalist narratives of ethnicity and territorial belonging, however they do not ultimately challenge the fishers' own self-identification as 
Sinhalese. Ultimately, this paper has suggested that fishers' stories of both mobility and confinement can be understood as both reinforcing and departing from the Sri Lankan state's own spatial imaginary of the island. In many important ways, the Mutuwall fishermen are more cosmopolitan than some of the Colombo middle classes; bi- or trilingual, familiar with parts of the island where many lifelong Colombo residents have never been, fishers provide a startling juxtaposition to contemporary, post-war development discourse which tends to erase the presence of the island's urban and rural poor.

Where "Colombo" has often featured in Sri Lankanist scholarship as shorthand for elites, westernized modes of living and disconnection from the rest of the island, this paper complicates our understanding of Colombo as category by attending to the non-elite experiences and histories that co-exist within the city alongside its more familiar upper middle-class inhabitants. The stories presented in this paper invite us, then, to think differently not only about Sri Lanka's actual coastlines but about the geographies of knowledge production in the study of Sri Lanka. From the vantage point of Mutuwall, questions of ethnic identity, power, security, conflict and mobility take new shape.

Amidst mounting geopolitical anxieties about control over Indian Ocean region, it is clear that "Indian Ocean studies" need not be relegated to examining the past, but rather can and should contribute to $21^{\text {st }}$ debates about space, politics and mobility. Sri Lanka is not peripheral but central to many of these debates. This paper has sought to use ethnography to shift ways of seeing Sri Lanka's island space with the goal of generating new conversations within Sri Lankan studies and beyond; ultimately this pushes us towards a truly contemporary mode of doing Indian Ocean studies. 


\section{References}

Amrith, Sunil. 2013. Crossing the Bay of Bengal: The Furies of Nature and the Fortunes of Migrants. Cambridge: Harvard University Press.

Blackburn, Anne. 2010. Locations of Buddhism: Colonialism and Modernity in Sri Lanka. Chicago/London: University of Chicago Press.

Biedermann, Zoltan and Strathern, Alan (eds). 2016. Sri Lanka at the Crossroads of History. London: University College London Press.

Bonta, Steven. 2010. "Negombo Fishermen's Tamil: A Case of Indo-Aryan Contact-Induced Change in a Dravidian Dialect" Anthropological Linguistics 52(3/4): 310-343.

Caron, Cynthia and Da Costa, Dia. "There's a Devil on Wayamba Beach: Social Dramas of Development and Citizenship in Northwest Sri Lanka" Journal of Asian and African Studies 42(5): 415-445.

Centre for Policy Alternatives. 2014. "Forced Evictions in Colombo: The Ugly Price of Beautification" Centre for Policy Alternatives Report.

Choi, Vivian. 2015. "Anticipatory States: Tsunami, War and Insecurity in Sri Lanka." Cultural Anthropology 30 (3): 286-309.

Frost, Mark. 2002. 'Wider Opportunities': Religious Revival, Nationalist Awakening and the Global Dimension in Colombo, 1870 - 1920." Modern Asian Studies 36 (4): 937-967.

Green, Nile. 2011. Bombay Islam: The Religious Economy of the West Indian Ocean, 18401915. Cambridge: Cambridge University Press.

Ho, Engseng. 2006. The Graves of Tarim: Genealogy and Mobility Across the Indian Ocean. Berkeley: University of California Press.

Hyndman, Jennifer. 2007. "The Securitization of Fear in Post-Tsunami Sri Lanka," Annals of the Association of American Geographers 97(2): 361-372.

Jazeel, Tariq. 2009. " Reading the geography of Sri Lankan island-ness: colonial repetitions, postcolonial possibilities" Contemporary South Asia 17 (4): 399-414.

. 2017. "Urban Theory With an Outside" Environment and Planning D 0(0): 1-15. Jeganathan, Pradeep. 2002. "Walking Through Violence: 'Everyday Life' and Anthropology." In Everyday Life in South Asia, edited by Diane P. Mines and Sarah Lamb. Indiana: Indiana University Press. 
Klem, Bart. 2014. “The political geography of war's end: Territorialisation, circulation, and moral anxiety in Trincomalee, Sri Lanka.” Political Geography 38: 33-45.

Lehman, Jessica. 2013. "Relating to the Sea: Enlivening the ocean as an actor in Eastern Sri Lanka"." Environment and Planning D 31.

McGilvray, Dennis. 1982. "Dutch Burghers and Portuguese Mechanics: Eurasian Ethnicity in Sri Lanka” Comparative Studies in Society and History 24(2): 235-263.

Nagaraj, Vijay. 2016. "From Smokestacks to Luxury Condos: The Housing Rights Struggle of the Millworkers of Mayura Place Colombo" Contemporary South Asia 24(4): 429-443.

Orjuela, Camilla. 2010. "The Bullet in the Living Room: Linking Security and Development in a Colombo Neighborhood” Security Dialogue 41(1): 99-120.

Perera, Nihal. 2002. "Indigenising the Colonial City: Late 19th-century Colombo and its Landscape." Urban Studies 39 (9):1703-1721.

Roberts, Michael. 1980. " From Southern India to Lanka: The traffic in commodities, bodies and myths from the thirteenth century onwards." South Asia: Journal of South Asian Studies 3 (1): 36-47.

Sivasundaram, Sujit. 2013. Islanded: Britain, Sri Lanka, and the Bounds of an Indian Ocean Colony. Chicago: University of Chicago Press.

Subramanian, Ajantha. 2009. Shorelines: Space and Rights in South India. Palo Alto: Stanford University Press.

Spencer, Jonathan. 2014. " Anthropology, Politics, and Place in Sri Lanka: South Asian Reflections from an Island Adrift" South Asia Multidisciplinary Academic Journal 10.

Spencer, J., Goodhand J., Hasbullah, S., Klem, B., Korf, B., Siva, K. .2014. Checkpoint, Temple, Church and Mosque: A Collaborative Ethnography of War and Peace. Pluto Press.

Thiranagama, Sharika. 2011. In My Mother's House: Civil War in Sri Lanka. Philadelphia: University of Pennsylvania Press. . 2012. "'A Railway to the Moon': The post-histories of a Sri Lankan railway line." Modern Asian Studies 46 (Special Issue 01):221-248.

Trawick, Margaret. 2007. Enemy Lines: Warfare, Childhood and Play in Batticaloa. Berkeley: University of California Press. 
Venugopal, Rajesh. 2018. Nationalism, Development and Ethnic Conflict in Sri Lanka. Cambridge: Cambridge University Press.

Walker, Rebecca. 2010. "Violence, the everyday and questions of the ordinary." Contemporary South Asia 18 (1).

Wenzlheumer, Roland. 2007. " Indian Labour Immigration and British Labour Policy in Nineteenth-Century Ceylon." Modern Asian Studies 41 (3): 575-602.

Wickremasinghe, Nira. 2006. Sri Lanka in the Modern Age: A History of Contested Identities. Sri Lanka: Vijitha Yapa Publications. 